\title{
Illegal settlement in the Babile Elephant Sanctuary is threatening the resident elephant population
}

Emily Neil and Elizabeth Greengrass

\begin{abstract}
The Babile Elephant Sanctuary in Ethiopia was established in 1970 specifically to protect its elephants Loxodonta africana. They were once part of a larger population that ranged in eastern Ethiopia and northern Somalia but that was largely extirpated during the 2oth century. Since its establishment, the Sanctuary has experienced severe anthropogenic pressure, inadequate government support, and civil conflict. Mapping was undertaken to analyse the rate of human immigration into the Sanctuary in 2006, 2014 and 2017, as part of an assessment of the Sanctuary's effectiveness in protecting its resident elephant population and in mitigating anthropogenic pressures. From 2006 to 2017 the number of illegal houses in the Sanctuary increased from 18,000 to $>50,000$, of which $>32,000$ were in the area in which elephants range. This settlement, coupled with high demand for natural resources, has resulted in significant habitat destruction and could also have exacerbated human-elephant conflict. Elephant conservation and monitoring by the Born Free Foundation were challenging because of ethnic conflict; rural and political stability is required if efforts to protect wildlife are to be successful. Unless these issues are resolved and the integrity of the Sanctuary is restored, this elephant population will be extirpated in the near future.
\end{abstract}

Keywords Babile Elephant Sanctuary, conflict, crop foraging, elephant conservation, encroachment, Ethiopia, paper park, protected area

\section{Introduction}

The establishment of protected areas is a key strategy for 1 the conservation of habitats and species, and the global loss of biodiversity would likely be even greater in their absence (Geldmann et al., 2013; Gray et al., 2016). Functioning ecosystems within protected areas can also play a part in poverty alleviation and economic development for surrounding communities (Naughton-Treves et al., 2005). However, protected areas vary greatly in their effectiveness

EmILY NeIL (Corresponding author, (D) orcid.org/0000-0001-8156-2344) University of Oxford, School of Geography and the Environment, South Parks Road, Oxford, OX1 3QY, UK. emily.neil@worc.ox.ac.uk

Elizabeth Greengrass ((D) orcid.org/0000-0002-2954-682X) Born Free Foundation, Horsham, UK

Received 7 February 2020. Revision requested 1 June 2020.

Accepted 13 October 2020. First published online 30 November 2021. and many are so-called paper parks, offering little to no protection. One third of the world's protected areas are under intense pressure from people (Jones et al., 2018), and without adequate funding and resources many are ill-equipped to manage the threats to biodiversity (Leverington et al., 2010; Coad et al., 2019).

In Africa, protected areas experienced a continent-wide halving in the abundance of large mammals between 1970 and 2005 (Craigie et al., 2010), and many populations are continuing to decline, largely because of the anthropogenic threats of overhunting, habitat conversion and resource competition with livestock (Ripple et al., 2015). This situation has probably been exacerbated by conflict, with the frequency of armed conflict the strongest predictor of wildlife declines in African protected areas (Daskin \& Pringle, 2018).

In Ethiopia, the integrity and effectiveness of many protected areas are being compromised by increasing anthropogenic pressures, inadequate government support, and civil conflict (Stephens et al., 2001; Yihune et al., 2009; Datiko \& Bekele, 2011; EWCA, 2015). With a growing human population of $>110$ million, there is a chronic shortage of land and a high demand for natural resources. These factors have contributed to the ongoing declines and extirpations of many large mammal species, such as the eastern black rhinoceros Diceros bicornis michaeli (Largen \& Yalden, 1987).

Elephants Loxodonta africana were once widespread and relatively abundant in Ethiopia, but they have suffered considerable declines since the beginning of the 2oth century (Largen \& Yalden, 1987; Dejene, 2016). The national population now consists of c. 1,00o individuals (Blanc et al., 2007). Poaching for the ivory trade, human population growth, associated destruction of natural habitat, and resulting human-elephant conflict are the most severe threats to their survival (Largen \& Yalden, 1987). Currently, there are only six recognized populations in Ethiopia, including one in the c. 7,000 $\mathrm{km}^{2}$ Babile Elephant Sanctuary (Largen \& Yalden, 1987; EWCA, 2015; Dejene, 2016), one of the largest protected areas in the country, in the Oromia and Somali regions (Fig. 1; Demeke, 2008).

In the 1970s, elephants migrated seasonally out of the Sanctuary, north of the Harar-Jigjiga road to the foothills of Gara Guracha and Gara Abdula, and far south and west of the Sanctuary (Demeke et al., 2012). Two subpopulations were documented: the larger ranged on the eastern side in the Dakata and Fafum valleys, and the smaller ranged on the western side, in the Erer valley. Since then, however, 


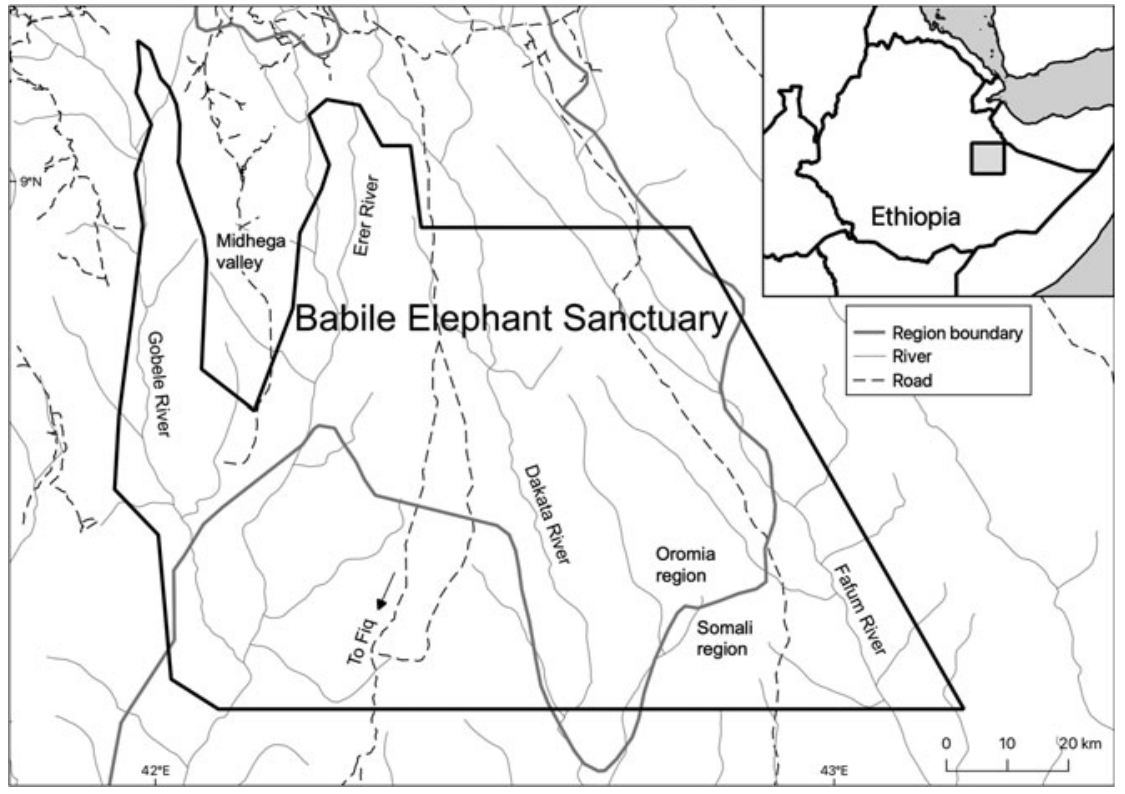

FIG. 1 The Babile Elephant Sanctuary, Ethiopia, and the Midhega valley, which was degazetted from the Sanctuary in 2007. The actual boundaries between the Oromia and Somali regions now differ significantly from the formal boundaries shown here; at the start of 2019, the whole area east of the Erer valley was considered to be within the Somali region. the elephant population has been threatened by agricultural expansion, settlement and commercial poaching (Demeke et al., 2012). In 1973, large government farms were established in the upper Fafum and upper Dakata valleys, outside the Sanctuary. Elephants came to these farms in search of water during the dry season, possibly because irrigation for agriculture led to shortages elsewhere. This exacerbated human-elephant conflict and retaliatory killing of elephants (Demeke, 2008). After 1975 these farms were taken over by local communities and cultivation spread southwards, occupying elephant habitat and watering points inside the Sanctuary (Demeke, 2008).

Regional boundaries in Ethiopia are established along ethnic lines, and ethnic conflict is common. The Oromo and Somali ethnic groups have a long history of conflict. In the border area of the Oromia and Somali regions, insecurity and the increased availability of guns during the Ethiopian-Somali war of 1977-1978 led to an increase in poaching and the establishment of refugee settlements within the elephant range, reportedly causing elephants to move from the eastern to the western side of the Sanctuary (Demeke et al., 2012). However, this explanation for the loss of elephants on the eastern side of the Sanctuary is speculative and an alternative explanation is extirpation, driven by conflict and poaching as a result of settlement and cultivation. In the 1980s, the government established 12 villages inside the Sanctuary and by 2007 the number had risen to 40 (Demeke, 2008).

Data collected during 2004-2008 indicated a population of 324 elephants in the Babile Elephant Sanctuary (Demeke et al., 2012). Elephants were only observed in the Erer and Gobele valleys on the western side of the Sanctuary, and seasonally in Dakata on the eastern side. Elephants no longer seemed to be undertaking long-distance migrations, with the southernmost limit of their range at the confluence of the Erer and Gobele valleys, within the Sanctuary. The elephants had lost $82 \%$ of their former range and only occupied $35 \%$ of the Sanctuary (Demeke et al., 2012). An increasing number of people shifted from pastoralism to agriculture at the beginning of the 21st century (Demeke et al., 2012), with farming in the upper Erer and Gobele valleys and beside an unsurfaced road that ran south to Fiq, a town in the Somali region, beyond the Sanctuary's southern boundary (Demeke, 2008).

In 2007, the Midhega valley, located between Gobele and Erer, was degazetted by the federal government, possibly to facilitate commercial development of the Flora Eco-Power biofuel project, which was established illegally inside the Sanctuary in 2006 and employed 250 skilled workers, 3,000 unskilled workers and 4,000 farmers who grew agricultural products on their own farms for sale to the company (Gebremeskel \& Tesfaye, 2008). Alternatively, it may have been an indirect response to the densely settled human population, which may have migrated into the area looking for work with the company. In 2014, an aerial survey by the Great Elephant Census described the Babile Elephant Sanctuary as 'an ocean of agriculture: 90\% of the sanctuary is settled by people' (Chase et al., 2014).

Approximately 100 elephant carcasses were counted inside the sanctuary during 2012-2013, and by 2015 the population had fallen to c. 250 individuals (A. Belayneh, pers. comm., 2015; Thouless et al., 2016). In 2016, the Born Free Foundation established an autonomous field project in the Sanctuary, to reduce elephant mortality caused by poaching and human-wildlife conflict. Born Free and the Ethiopian Wildlife Conservation Authority had a Memorandum of Understanding to co-manage activities in the Sanctuary, with Born Free mandated to take the lead in project delivery 
and to build the Ethiopian Wildlife Conservation Authority's capacity at the site. Mobilization of Ethiopian Wildlife Conservation Authority rangers meant that the elephants were monitored daily, with data on their ranging and herd size recorded. This demonstrated that the elephant range was limited to the Erer and Gobele valleys, and humanelephant conflict was severe and a significant cause of elephant mortality in addition to poaching (Born Free, unpubl. data, 2016-2019). In 2017, the project piloted chilli-fencing as a mitigation measure on a farm and was successful in protecting crops from elephants.

Throughout the latter half of 2016 until 2018, chronic ethnic conflict between the Oromo and Somali ethnic groups, although sporadic, was a characteristic around which the Born Free project had to work. At times, it hampered project operations and the monitoring and safe guarding of the elephant population, in part because the areas in which rangers could safely patrol were limited. To assess the overall effectiveness of the protected area in mitigating anthropogenic pressures, mapping was undertaken in 2018 to measure the rate of human immigration into the Sanctuary.

\section{Methods}

To assess the rate of immigration over time, we counted the number of houses in the Babile Elephant Sanctuary using satellite imagery from 2006, 2014 and 2017. At the time of analysis these were the years for which satellite images with a sufficiently high resolution to facilitate the counting of individual houses were freely available. When we began this research in 2018, the most recent satellite imagery of the Sanctuary available was for 2014, from Google Earth (Google, Mountain View, USA), which provides a mosaic of satellite images; the region analysed primarily comprised images from Maxar (Maxar Technologies, Westminster, USA; spatial resolution $0.5 \mathrm{~m}$ ). Satellite imagery of the sanctuary for 2017 later became freely available on the World Imagery Wayback platform (Esri, Redlands, USA), which also uses compilations of satellite images, primarily from Maxar. We accessed satellite images for 2006 from the World Imagery Wayback platform; these primarily comprised images from CNES/Airbus DS (CNES, Paris, France, and Airbus, Leiden, The Netherlands; spatial resolution: $2.5 \mathrm{~m}$ ). Although the Midhega valley was not degazetted from the Sanctuary until 2007, the region was excluded from the 2006 analysis to ensure the study area remained consistent across the three years.

A limitation of using the freely available satellite imagery is that it comprises many images blended together, from different sources and different years. For example, the 2006 satellite imagery included some imagery from 2008, from DigitalGlobe (DigitalGlobe, Westminster, USA; resolution: $0.5 \mathrm{~m}$ ), and from 2007, from GeoEye (GeoEye, Herndon, USA; Ikonos, resolution: $1 \mathrm{~m}$ ), and it was not possible to determine the exact proportion of the image that came from different years, although the greatest proportion was from 2006. The number of housing structures can therefore only be considered a proxy for the number of houses in a particular year.

We analysed satellite images using ArcGIS 1.6.1 (Esri, Redlands, USA), counting houses by eye in $1 \times 1 \mathrm{~km}$ grid cells. Permanent housing was classified as any structure $>7 \mathrm{~m}$ in length or width, with roofs of grass or corrugated metal sheet. Temporary houses were circular structures $<7 \mathrm{~m}$ in diameter; our observations in the Sanctuary suggest these were made from tarpaulin on a wooden frame, or mud. Because of their size, permanent mud and metalroofed houses were readily identifiable whereas temporary housing was more difficult to identify unless located in clearings and farmland. If it was unclear whether a shape was a housing structure or a natural feature of a similar size (e.g. boulder), it was not counted; the number of temporary houses may therefore be an underestimate. Given the size of the area, the extent of settlement and the fact that houses were counted manually, we may have not counted all houses. Change in the number of metal-roofed houses is probably the most reliable indicator of settlement rates as these were readily visible and therefore less likely to be undercounted.

Firstly, we counted houses within the area of the Sanctuary occupied by elephants, which lies on the western side of the Sanctuary and was defined by the location of elephant herds observed by ranger patrols during 20162018. Secondly, we counted the number of houses outside this elephant range, and then calculated the rate of change in settlement within and outside the elephant range, and overall.

The kernel density estimation (Silverman, 1986) tool in ArcGIS was used to analyse the density of settlements in the Sanctuary in 2006, 2014 and 2017. This method is widely used to analyse spatial patterns and has been applied in a variety of fields, including housing growth (Delmelle et al., 2014), road accidents (Prasannakumar et al., 2011) and crime analysis (Rey et al., 2012). Kernel density estimation shows the number of events (e.g. settlements) per unit area and is therefore useful in detecting hotspots of events.

\section{Results}

In 2006, there were c. 18,000 permanent and temporary houses or similar structures in the Babile Elephant Sanctuary (excluding the Midhega valley). By 2014, this had more than doubled to almost 40,000 (Table 1), and by 2017 this had increased by a further $25 \%$ to c. 50,000 . The mean annual increase in the number of houses was similar from 2006 to $2014(2,750)$ and from 2014 to 2017 $(3,330)$. In general, the density of settlements decreased 
TABLE 1 Number of houses, counted from satellite imagery, within and outside elephant Loxodonta africana range in the Babile Elephant Sanctuary, Ethiopia, in 2006, 2014 and 2017.

\begin{tabular}{|c|c|c|c|c|c|c|c|c|c|}
\hline & \multicolumn{3}{|c|}{ Within elephant range } & \multicolumn{3}{|c|}{ Outside elephant range } & \multicolumn{3}{|l|}{ Total } \\
\hline & 2006 & 2014 & 2017 & 2006 & 2014 & 2017 & 2006 & 2014 & 2017 \\
\hline Permanent, metal-roofed & 300 & 1,591 & 2,371 & 105 & 870 & 1,104 & 405 & 2,461 & 3,475 \\
\hline Permanent, mud & 692 & 1,502 & 1,986 & 332 & 356 & 451 & 1,024 & 1,858 & 2,437 \\
\hline Temporary & 8,239 & 25,501 & 28,445 & 8,256 & 10,078 & 15,709 & 16,495 & 35,579 & 44,154 \\
\hline Total & 9,231 & 28,594 & 32,802 & 8,693 & 11,304 & 17,264 & 17,924 & 39,898 & 50,066 \\
\hline
\end{tabular}

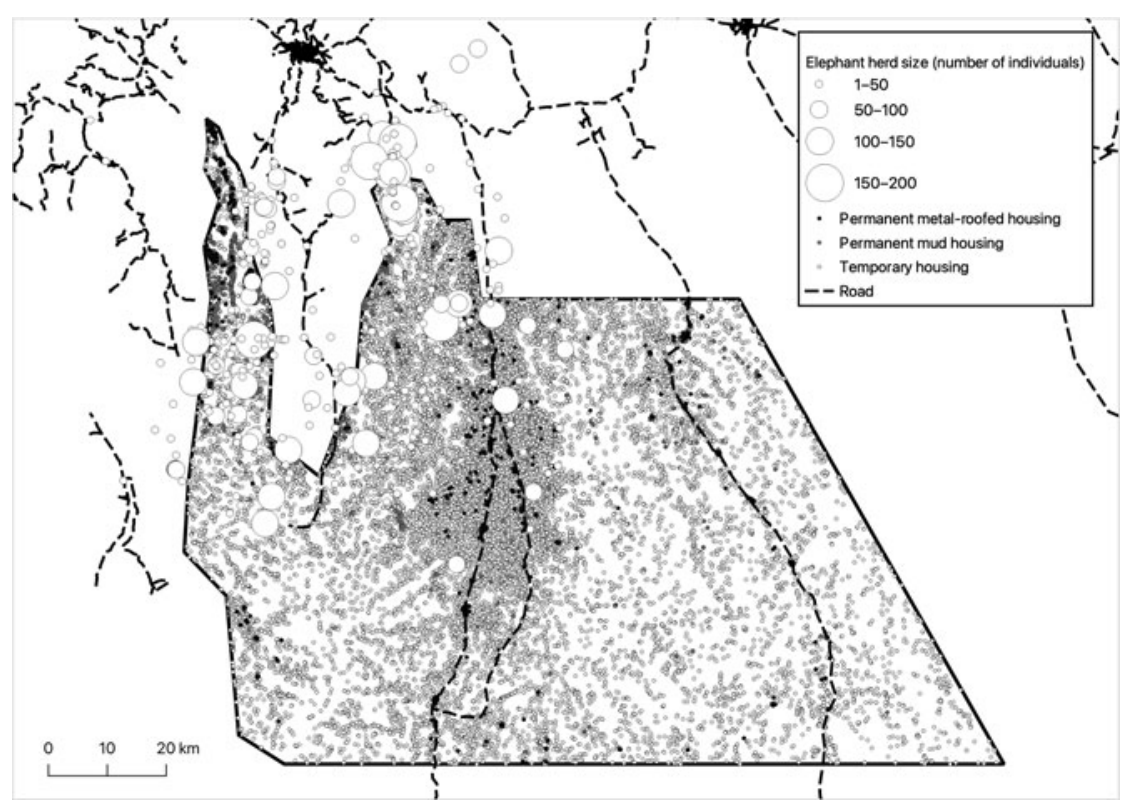

Fig. 2 Houses and other building structures within the Babile Elephant Sanctuary in 2017 , identified from satellite imagery, and elephant ranging data from the Born Free Foundation's 2016-2019 patrol data.

from north to south, indicating immigration from the areas north of the Sanctuary.

Within the area of the Sanctuary where elephants currently range, there was an almost four-fold increase in the number of houses from 2006 to 2017 (Table 1, Fig. 2), with a higher rate of increase from 2006 to 2014 (mean annual increase of 2,438 houses) than from 2014 to 2017 (mean annual increase of 1,433). Permanent housing with corrugated metal roofing increased almost nine-fold over the 12-year period, with an eight-fold increase within the elephant range.

In 2006, 2014 and 2017 there were hotspots of settlement along the road that runs north-south through the Sanctuary (Fig 3). This road passes through the Somali region to the town of Fiq, south of the Sanctuary, and was being upgraded and surfaced when we visited at the start of 2019. By 2014 most of the densely settled regions were along this road, to a lesser extent in the upper Erer and Gobele valleys, and along an unpaved road in the east of the Sanctuary in Fafum valley, which in 2019 was also reportedly being upgraded in some way. Figures 2 and 3 suggest that the road to Fiq is facilitating settlement. Housing hotspots had expanded along this road by 2017 , encompassing the majority of the elephants' range.

\section{Discussion}

Uncontrolled settlement inside the Babile Elephant Sanctuary has been ongoing since the 1970s (Demeke, 2008), but the current rate is unprecedented. One consequence of this is that the boundary between the Oromia and Somali regions no longer resembles the formal boundary shown in Fig. 1. At the start of 2019, the whole area east of the Erer valley was considered to be within the Somali region (Born Free, pers. comm., 2019). There has also been an associated expansion of forest conversion and cultivation. A study conducted in 2017 showed that agricultural land, settlements, and bare land increased during 19772017, and riparian forest, woodland and bushland, habitats used by elephants, declined (Sintayehu \& Kassaw, 2019). Agriculture is particularly prevalent in that part of the Sanctuary within the Oromia region but overgrazing by livestock is also a potential problem (EG, pers. obs., 2015).

Water tankers from Harar regularly deliver water to villages bordering the Sanctuary (authors, pers. obs., 2019), suggesting that natural water sources are insufficient to meet the needs of local communities. In an already waterscarce region, the expansion of cash crop farming in and 

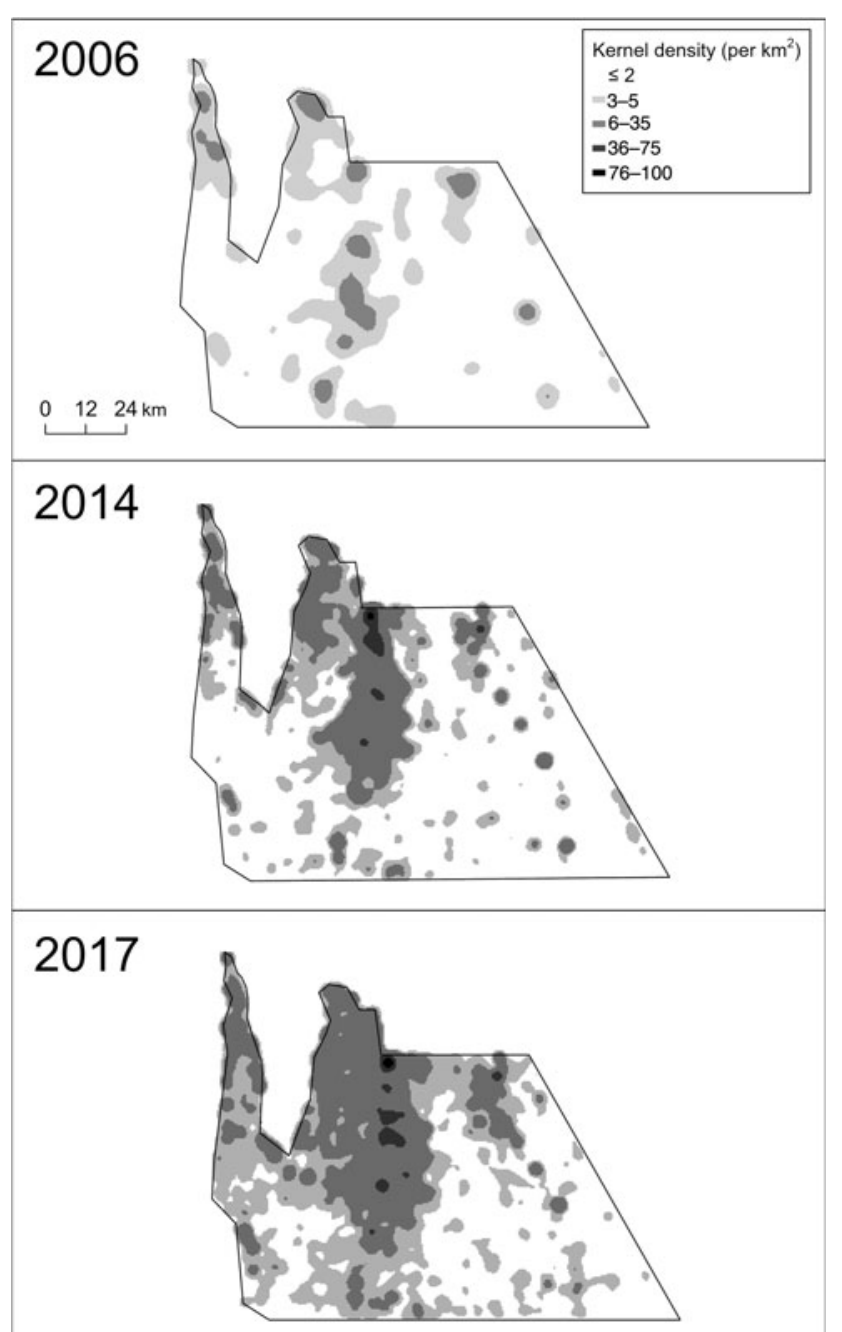

FIG. 3 Hotspots of settlement in the Babile Elephant Sanctuary in 2006, 2014 and 2017, identified using the kernel density estimation tool in ArcGIS. Settlements are concentrated in the north-central region of the Sanctuary, in the area in which elephants range (Fig. 2).

around the Sanctuary may also be contributing to water shortages through irrigation. Khat, which is a widely-used mild stimulant and a high-value cash crop grown extensively in the region, requires substantial amounts of water (Gebissa, 2010). The Gobele River, which was permanent in the 1970s (Stephenson, 1976) no longer flows year-round, and the Erer River, which is normally permanent, was dry at the start of the 2019 wet season, with people observed digging the riverbed by hand to extract water (authors, pers. obs., 2019).

Water availability is a key determinant of habitat use, movement and distribution of elephants, as they need to drink every 2-3 days (Redfern et al., 2003; ChamailléJammes et al., 2007; Loarie et al., 2009). Elephant range in the Sanctuary is confined to the Erer and Gobele valleys (Fig. 2), probably reflecting the dependence of elephants on the Erer River. Anthropogenic activities may be affecting this water source (authors, pers. obs., 2019) and exacerbating impacts caused by climate change. Our finding of a high rate of settlement in the area is indicative of high rates of natural resource exploitation. Periods of drought can significantly increase elephant mortality (Dudley et al., 2001; Foley et al., 2008), reduce female reproductive capacity (Sinclair, 1975; Wittemyer et al., 2013), and deplete local forage, leading to starvation (Wato et al., 2016) and potentially to an increase in human-elephant conflict by forcing people, livestock and elephants to share the few sparsely distributed water sources.

During 2016-2019 almost a third of all incidents of human-elephant conflict within and around the Sanctuary occurred within it, highlighting the extent to which the Sanctuary is being used by local communities (Born Free, unpubl. data, 2016-2019). Where there is conflict, poaching may be more tolerated and human deaths and injuries from elephants, retaliatory killings of elephants, livestock deaths and injuries, crop foraging, and conflict at water points, are all commonly recorded (Born Free, unpubl. data, 20162019). Loss of many of the preferred food species of the elephants (Belayneh \& Demissew, 2011) could be exacerbating crop foraging. When they overlap spatially with humans, elephants avoid roads, villages and infrastructure (Barnes et al., 1991; Roever et al., 2013; Songhurst et al., 2016), or alter the speed or timing of their movements, in areas where people are perceived as hostile (Graham et al., 2009; Ihwagi et al., 2018). Current levels of human settlement and humanelephant conflict in the Babile Elephant Sanctuary suggest that elephants may be finding it difficult to locate the resources they need and to avoid areas with high human presence.

The factors promoting immigration into the Sanctuary are not well understood and social surveys were not undertaken while the project was active. However, our observations suggest that within the context of a burgeoning rural human population dependent on scarce natural resources, a shortage of land, and a disempowered, under-resourced protected area management system, infrastructure development has exacerbated the situation. In the latter half of 2016 the Ethiopian Prime Minister declared the first National State of Emergency, which authorized the military to enforce security nationwide and imposed restrictions on freedom of speech and access to information in response to protests against the government. Since then, there has been a perception amongst Sanctuary and Born Free project personnel that local communities were taking advantage of weakened law and order to claim land, although the rates of settlement were similar during the two time periods we analysed and thus we do not have evidence to support this.

A survey during 2004-2007 found that the majority of people encroaching in the Babile Elephant Sanctuary came from villages located just outside the Sanctuary, and already had land elsewhere (Demeke, 2008). Although widespread 
land shortage is a major issue in Ethiopia, this suggests that other issues may be driving or contributing to immigration, such as the lack of management deterrents and ineffective law enforcement. Ethnic conflict, on the other hand, did not appear to be a direct driver of immigration. During a visit in 2019, the majority of internally displaced people were being housed in camps outside the Sanctuary, before eventually returning to their town and villages, although a few had settled inside the Sanctuary (EG, pers. obs., 2019). However, ethnic conflict appeared to be a contributing factor: it weakened the law enforcement capabilities of rangers at the Sanctuary, as the ethnicity of the rangers determined which areas they could patrol safely (EG, pers. obs., 2017).

Our findings suggest that the upgrading of the road to Fiq has been a catalyst for settlement, as noted elsewhere along linear developments such as roads, railway and power lines (Laurance et al., 2009). As Ethiopia is a federal state, much of the power outside Addis Ababa is devolved to regional governments. The road to Fiq was commissioned by the Somali regional government, but we do not know whether consent was granted from the federal government; a breakdown of law and order, coupled with the division of regions along ethnic lines since 1991, has, we understand, created a degree of regional autonomy. We were also unable to confirm whether an environmental and social impact assessment had been prepared for the upgrading of the road (EG, pers. obs., 2019). Although the road, which was commissioned by a regional government, is within a federal protected area, no federal government agency has been tasked with addressing the negative impacts of road development on the protected area.

Local pressures on land, including industrial agriculture, subsistence and human habitation are some of the most common drivers of the downgrading, downsizing and degazettement of protected areas (Mascia et al., 2014; Pack et al., 2016). Downgrading, downsizing and degazettement can lead to increased pressures and result in negative ecological effects such as habitat loss and fragmentation (Forrest et al., 2014; Kroner et al., 2016), and may be an additional driver of settlement in the Babile Elephant Sanctuary. The federal government's demarcation of the boundary of the Sanctuary, begun in 2007 , has not been completed (Demeke \& Aklilu, 2008) yet there has already been degazettement of a large section of the Sanctuary, in the Midhega valley, which supported high densities of people and elephants. In 2019, there were unconfirmed reports that the Somali region of the Sanctuary, which at that time represented the greatest proportion, would be degazetted. Within a context of chronic civil instability, poverty and food insecurity, the government may be reticent to take decisions that may be perceived as disadvantageous to local communities. We believe, however, that environmental and poverty challenges in the Sanctuary need to be addressed jointly. The dependence of local communities on subsistence use of natural resources, and trade of resources such as charcoal, from the Sanctuary (EG, pers. obs., 2019) are exacerbating environmental degradation and, we believe, the well-being and prosperity of these communities (Scherr, 2000; Kassa et al., 2018).

When managed well, protected areas can conserve biodiversity effectively (Watson et al., 2014). However, uncontrolled immigration and settlement threaten the Babile Elephant Sanctuary, compromising its integrity and elephant conservation efforts within a complex socio-political context of a weak state and ethnic conflict. We believe that unless the integrity of the Sanctuary can be restored, and security and poverty issues resolved, the elephants of the Babile Elephant Sanctuary will be extirpated within a short time, marking a significant failure on the part of all stakeholders.

Acknowledgements $\mathrm{We}$ are grateful to the Ethiopian Wildlife Conservation Authority for permission to work in the Babile Elephant Sanctuary, and to Zelealem Tefera, Motuma Adula, Peter Kenchington, and the Babile Elephant Sanctuary ranger team for their fieldwork. Work was funded by the Born Free Foundation, the Elephant Crisis Fund through Save the Elephants, and the U.S. Fish \& Wildlife African Elephant Fund.

Author contributions Data collection, analysis: EN; study design, framework: EG; writing: both authors.

\section{Conflicts of interest None.}

Ethical standards This research abided by the Oryx guidelines on ethical standards.

\section{References}

Barnes, R.F.W., Barnes, K.L., Alers, M.P.T. \& Blom, A. (1991) Man determines the distribution of elephants in the rain forests of northeastern Gabon. African Journal of Ecology, 29, 54-63.

Belayneh, A. \& Demissew, S. (2011) Diversity and population structure of woody species browsed by elephants in Babile Elephant Sanctuary, eastern Ethiopia: an implication for conservation.

Ethiopian e-Journal for Research and Innovation Foresight, 3, 20-32.

Blanc, J.J., Barnes, R.F.W., Craig, G.C., Dublin, H.T., Thouless, C.R., Douglas-Hamilton, I. \& Hart, J.A. (2007) African

Elephant Status Report 2007: An Update from the African Elephant Database. IUCN, Gland, Switzerland.

Chamaillé-Jammes, S., Valeix, M. \& Fritz, H. (2007) Managing heterogeneity in elephant distribution: interactions between elephant population density and surface-water availability. Journal of Applied Ecology, 44, 625-633.

Chase, M. (2014) Survey Update Ethiopia: People Dominate Elephant Sanctuary. Great Elephant Census. greatelephantcensus.com/blog/ 2014/5/16/survey-update-ethiopia-people-in-the-sanctuary [accessed 28 July 2021].

Coad, L., Watson, J.E., Geldmann, J., Burgess, N.D., Leverington, F., Hockings, M. et al. (2019) Widespread shortfalls in protected area resourcing undermine efforts to conserve biodiversity. Frontiers in Ecology and the Environment, 17, 259-264. Craigie, I.D., Baillie, J.E.M., B Almford, A., Carbone, C., Collen, B., Green, R.E. \& Hutton, J.M. (2010) Large mammal population 
declines in Africa's protected areas. Biological Conservation, 143, 2221-2228.

Daskin, J.H. \& Pringle, R.M. (2018) Warfare and wildlife declines in Africa's protected areas. Nature, 553, 328-332.

Datiko, D. \& Berele, A. (2011) Population status and human impact on the Endangered Swayne's hartebeest (Alcelaphus buselaphus swaynei) in Nechisar Plains, Nechisar National Park, Ethiopia. African Journal of Ecology, 49, 311-319.

Dejene, S.W. (2016) The African elephant (Loxodonta africana) in Ethiopia: a review. European Journal of Biological Sciences, 8, 8-13.

Delmelle, E.C., Zhou, Y. \& Thill, J.-C. (2014) Densification without growth management? Evidence from local land development and housing trends in Charlotte, North Carolina, USA. Sustainability, 6, 3975-3990.

DemeKe, Y. (2008) The ecology and conservation of the relic elephant population in the Horn of Africa. $\mathrm{PhD}$ thesis, University of Melbourne, Melbourne, Australia.

Demeкe, Y. \& A klilu, N. (2008) Alarm Bell for Biofuel Development in Ethiopia: The Case of Babile Elephant Sanctuary (Agrofuel Development in Ethiopia: Rhetoric, Reality, Recommendations, pp. 83-113). Forum for Environment, Addis Ababa, Ethiopia.

Demeke, Y., Renfree, M.B. \& Short, R.V. (2012) Historical range and movements of the elephants in Babile Elephant Sanctuary, Ethiopia. African Journal of Ecology, 50, 439-445.

Dudley, J.P., Criag, G.C., Gibson, D.S.C., Haynes, G. \& KLimowicz, J. (2001) Drought mortality of bush elephants in Hwange National Park, Zimbabwe. African Journal of Ecology, 39, 187-194.

EWCA (Ethiopian Wildlife Conservation Authority) (2015) Ethiopian Elephant Action Plan: 2015-2025. Addis Ababa, Ethiopia.

Foley, C., Pettorelli, N. \& Foley, L. (2008) Severe drought and calf survival in elephants. Biology Letters, 4, 541-544.

Forrest, J.L., Mascia, M.B., Pailler, S., Abidin, S.Z., Araujo, M.D., Krithivasan, R. \& Riveros, J.C. (2014) Tropical deforestation and carbon emissions from protected area downgrading, downsizing, and degazettement (PADDD). Conservation Letters, 8, 153-161.

Gebissa, E. (2010) Taking the Place of Food: Khat in Ethiopia. Red Sea Press, Trenton, USA.

Gebremeskel, L. \& Tesfaye, M. (2008) A Preliminary Assessment of Socioeconomic and Environmental Issues Pertaining to Liquid Biofuel Development in Ethiopia (Agrofuel Development in Ethiopia: Rhetoric, Reality, Recommendations, pp. 39-65). Forum for Environment, Addis Ababa, Ethiopia.

Geldmann, J., Barnes, M., Coad, L., Craigie, I.D., Hockings, M. \& Burgess, N.D. (2013) Effectiveness of terrestrial protected areas in reducing habitat loss and population declines. Biological Conservation, 161, 230-238.

Graham, M.D., Douglas-Hamilton, I., Adams, W.M. \& Lee, P.C. (2009) The movement of African elephants in a human-dominated land-use mosaic. Animal Conservation, 12, 445-455.

Gray, C.L., Hill, S.L.L., Newbold, T., Hudson, L.N., Börger, L., Contu, S. et al. (2016) Local biodiversity is higher inside than outside terrestrial protected areas worldwide. Nature Communications, 7, 12306.

Ihwagi, F.W., Thouless, C., Wang, T., Skidmore, A.K., Omondi, P. \& Douglas-Hamilton, I. (2018) Night-day speed ratio of elephants as indicator of poaching levels. Ecological Indicators, $84,38-44$.

Jones, K.R., Venter, O., Fuller, R.A., Allan, J.R., Maxwell, S.L., Negret, P.J. \& Watson, J.E.M. (2018) One-third of global protected land is under intense human pressure. Science, $360,788-791$.
Kassa, G., Teferi, B. \& Delelegn, N. (2018) The povertyenvironment nexus in developing countries: evidence from Ethiopia: a systematic review. Asian Journal of Agricultural Extension, Economics \& Sociology, 24, 1-13.

Kroner, R.E., Krithivasan, R. \& Mascia, M.B. (2016) Effects of protected area downsizing on habitat fragmentation in Yosemite National Park (USA), 1864-2014. Ecology and Society, 21, 22.

Largen, M.J. \& Yalden, D.W. (1987) The decline of elephant and black rhinoceros in Ethiopia. Oryx, 21, 103.

Laurance, W., Goosem, M. \& Laurance, S. (2009) Impacts of roads and linear clearings on tropical forests. Trends in Ecology \& Evolution, 24, 659-669.

Leverington, F., Costa, K.L., Pavese, H., Lisle, A. \& Hockings, M. (2010) A global analysis of protected area management effectiveness. Environmental Management, 46, 685-698.

Loarie, S.R., Aarde, R.J.V. \& Pimm, S.L. (2009) Fences and artificial water affect African savannah elephant movement patterns. Biological Conservation, 142, 3086-3098.

Mascia, M.B., Pailler, S., Krithivasan, R., Roshchanka, V., Burns, D., Mlotha, M.J. et al. (2014) Protected area downgrading, downsizing, and degazettement (PADDD) in Africa, Asia, and Latin America and the Caribbean, 1900-2010. Biological Conservation, 169, 355-361.

Naughton-Treves, L., Holland, M.B. \& Brandon, K. (2005) The role of protected areas in conserving biodiversity and sustaining local livelihoods. Annual Review of Environment and Resources, 30, 219-252.

Pack, S.M., Ferreira, M.N., Krithivasan, R., Murrow, J., Bernard, E. \& Mascia, M.B. (2016) Protected area downgrading, downsizing, and degazettement (PADDD) in the Amazon. Biological Conservation, 197, 32-39.

Prasannakumar, V., Vijith, H., Charutha, R. \& Geetha, N. (2011) Spatio-temporal clustering of road accidents: GIS based analysis and assessment. Procedia - Social and Behavioral Sciences, 21, 317-325.

Redfern, J.V., Grant, R., Biggs, H. \& Getz, W.M. (2003) Surface-water constraints on herbivore foraging in the Kruger National Park, South Africa. Ecology, 84, 2092-2107.

Rey, S.J., Mack, E.A. \& Koschinsky, J. (2012) Exploratory spacetime analysis of burglary patterns. Journal of Quantitative Criminology, 28, 509-531.

Ripple, W.J., Newsome, T.M., Wolf, C., Dirzo, R., Everatt, K.T., Galetti, M. et al. (2015) Collapse of the world's largest herbivores. Science Advances, 1, e1400103.

Roever, C.L., van Aarde, R.J. \& Leggett, K. (2013) Functional connectivity within conservation networks: delineating corridors for African elephants. Biological Conservation, 157, 128-135.

SCHERR, S.J. (2000) A downward spiral? Research evidence on the relationship between poverty and natural resource degradation. Food Policy, 25, 479-498.

Silverman, B.W. (1986) Density Estimation for Statistics and Data Analysis. Chapman and Hall, London, UK.

Sinclair, A. (1975) The resource limitation of trophic levels in tropical grassland ecosystems. Journal of Animal Ecology, 44, 497-520.

Sintayehu, D.W. \& KasSAW, M. (2019) Impact of land cover changes on elephant conservation in Babile Elephant Sanctuary, Ethiopia. Biodiversity International Journal, 3, 7 .

Songhurst, A., McCulloch, G. \& Coulson, T. (2016) Finding pathways to human-elephant coexistence: a risky business. Oryx, 50, 713-720.

Stephens, P.A., D'SA, C. A., Sillero-Zubiri, C. \& LeaderWilliams, N. (2001) Impact of livestock and settlement on the large mammalian wildlife of Bale Mountains National Park, Southern Ethiopia. Biological Conservation, 100, 307-322. 
Stephenson, J.G. (1976) Reports on the Harar Elephant Dilemma. Ethiopian Wildlife Conservation Organization, Addis Ababa, Ethiopia.

Thouless, C., Dublin, H.T., Blanc, J.J., Skinner, D.P., Daniel, T.E., TA Y LOR, R.D. et al. (2016) African Elephant Status Report 2016: An Update from the African Elephant Database. Occasional paper of the IUCN Species Survival Commission. IUCN/SSC African Elephant Specialist Group, Gland, Switzerland.

Wato, Y.A., Heit König, I.M.A., VAn Wieren, S.E., Wahungu, G., Prins, H.H.T. \& van Langevelde, F. (2016) Prolonged drought results in starvation of African elephant (Loxodonta africana). Biological Conservation, 203, 89-96.

Watson, J.E.M., Dudley, N., Segan, D.B. \& Hockings, M. (2014)

The performance and potential of protected areas. Nature, 515, 67-73. Wittemyer, G., Daballen, D. \& Douglas-Hamilton, I. (2013) Comparative demography of an at-risk African elephant population. PLOS ONE, 8, e53726.

Yihune, M., BeKele, A. \& Tefera, Z. (2009) Human-wildlife conflict in and around the Simien Mountains. Ethiopian Journal of Science, $32,57-64$. 